\title{
Secondary Science Teachers' Views on Environmental Citizenship in The Netherlands
}

\author{
Michiel van Harskamp *(D), Marie-Christine P. J. Knippels (D) and Wouter R. van Joolingen
}

Freudenthal Institute, Department of Mathematics, Utrecht University, P.O. Box 85170, 3508 AD Utrecht, The Netherlands; m.c.p.j.knippels@uu.nl (M.-C.P.J.K.); w.r.vanjoolingen@uu.nl (W.R.v.J.)

* Correspondence: m.vanharskamp@uu.nl; Tel.: +31-30-253-8251

Citation: van Harskamp, M.; Knippels, M.-C.P.J.; van Joolingen, W.R. Secondary Science Teachers' Views on Environmental Citizenship in The Netherlands. Sustainability 2021, 13, 7963. https://doi.org/ $10.3390 /$ su13147963

Academic Editor: Changwoo Ahn

Received: 14 June 2021

Accepted: 13 July 2021

Published: 16 July 2021

Publisher's Note: MDPI stays neutral with regard to jurisdictional claims in published maps and institutional affiliations.

Copyright: (c) 2021 by the authors. Licensee MDPI, Basel, Switzerland. This article is an open access article distributed under the terms and conditions of the Creative Commons Attribution (CC BY) license (https:// creativecommons.org/licenses/by/ $4.0 /)$.

\begin{abstract}
Environmental Citizenship (EC) is a promising aim for science education. EC enables people not only to responsibly make decisions on sustainability issues-such as use of renewable energy sources-but also to take action individually and collectively. However, studies show that education for EC is challenging. Because our understanding of EC practice remains limited, an indepth, qualitative view would help us better understand how to support science teachers during EC education. This study aims to describe current EC education practices. What do secondary science teachers think sustainability and citizenship entail? What are their experiences (both positive and negative) with education for EC? A total of 41 Dutch science teachers were interviewed in an individual, face-to-face setting. Analysis of the coded transcripts shows that most teachers see the added value of EC but struggle to fully implement it in their teaching. They think the curriculum is unsuitable to reach EC, and they see activities such as guiding discussions and opinion forming as challenging. Furthermore, science teachers' interpretation of citizenship education remains narrow, thus making it unlikely that their lessons are successful in fostering EC. Improving EC education therefore may be supported by explicit representation in the curriculum and teacher professional development directed at its implementation.
\end{abstract}

Keywords: environmental citizenship; lower secondary level; science education; science teachers; education for environmental citizenship

\section{Introduction}

Societies are dealing with complex environmental issues such as climate change, energy crises, and degradation of natural areas. These issues create a need for citizens who are analytic, who can make decisions based on personal, social, and scientific considerations, and who are able to put these into practice. In other words, these issues raise the need for Environmental Citizenship (EC). The importance of EC is shown by educational programs of large international organizations across the globe. For example, the Lifelong Learning Competences of the EU explicitly feature sustainability elements in their description of citizenship competence [1]. Another example is the Sustainable Development Goals, set by the UN, in order to globally align policies and development plans with the sustainability agenda [2]. Finally, the UN organized the Decade of Education for Sustainable Development, which lasted from 2005-2014, and aimed to push the sustainability agenda on schools worldwide [3].

However, this focus on EC in educational policy does not necessarily result in more EC being implemented in the classroom. In education, much depends on the choices of the teacher. When science teachers do not see the value of EC, chances are slim for their students to develop EC on their own. Previous large scale, quantitative studies have shown that many science teachers feel unprepared and unsure when teaching about sustainability and its related SSIs [4,5]. However, because most of these studies adopted a quantitative approach, there is a need for in-depth interview study to provide a qualitative 
view on science teacher's perceptions on and experience with teaching sustainability at the secondary level [4]. If we would better understand what teachers are struggling with and what possibilities they foresee, we would be better equipped to support teachers during EC teaching. Hereby, we would improve chances of fostering EC.

In this paper, we aim to describe the current situation of education for EC in the Netherlands at the lower secondary level by answering the following questions: What do Dutch science teachers think sustainability and citizenship entail? What are their experiences (both positive and negative) with education for EC in classroom practice? Describing this current state is a first step in better understanding what challenges exist, and where the research community could support science teachers in education for EC.

\subsection{Definitions of EC and Related Concepts}

The last decades of research on sustainability education have resulted in insights in teacher experiences with EC in science education. Results from these, mostly quantitative, studies will be discussed in this section, but not before making a statement as to the interpretation of EC and its relation to sustainability, sustainable development, and educational approaches towards these topics.

Although many definitions of sustainability exist, one of the most widely used is the Brundtland definition, from the famous Our Common Future report. This report defines sustainable development as "development that meets the needs of the present without compromising the ability of future generations to meet their own needs" [6] (p. 41). To make this sustainable future into a reality, citizens need a specific set of knowledge, attitudes, and behavior that enables them to deal with sustainability issues in their daily lives. This form of citizenship consists of diverse competences such as systems thinking, normative competences, future thinking, and strategic thinking. An Environmental Citizen performs these actions individually and in groups, both in private and public spheres, and on local, national, and global scales [7]. In doing so, environmental citizens aim to solve contemporary issues, prevent new ones, and achieve sustainability through this, among others. EC thereby encompasses elements of all three types of citizen as defined by Westheimer and Kahne [8]: (i) the personally responsible citizen, who acts responsibly, is law abiding, and honest; (ii) the participatory citizen, who actively participates and takes leadership positions in existing systems; (iii) and the social-justice oriented citizen, who questions, debates, and changes these existing systems.

Two common teaching approaches that can foster EC are Environmental Education (EE) and Education for Sustainable Development (ESD). Despite sharing certain aspects, they differ considerably in their ideological focus [9]. EE explores humanity's relationship with nature and aims to preserve natural areas. It focuses strongly on scientific content knowledge. ESD, on the other hand, adopts a broader view which also considers social, economic and cultural elements. A common theme in ESD is the triple bottom line of sustainability, which consists of people, planet and prosperity [10]. This broader focus of ESD, and especially its supposed overemphasis of economic aspects of sustainability issues, has received criticism from scholars. They argue that by moving away from EE towards ESD, the inherent value of nature no longer has a place in the science classroom [11]. Other researchers see EE and ESD next to each other, both with their own niche and focus [9]. A third form exists, which combines elements of EE and ESD, in such a way as to address "knowledge, skills, values and affective issues for a changing future without losing sight of the imperative for understanding and valuing conservation of the biophysical world" [12] (p. 104). This form is called Education for Sustainability (EfS). A synthesis of the concepts EE and EfS, with a special focus on citizenship, is Education for Environmental Citizenship (EEC), which aims to empower students to become responsible environmental citizens [7]. 


\subsection{Teachers' Conceptual Understanding of Sustainability and Citizenship}

There have been several quantitative studies looking into teachers' conceptual understanding of sustainability, i.e., [4,13-15]. Judging by these, sustainability is a difficult concept for teachers to define. In a large questionnaire study with over 3000 Swedish teachers, many different teacher interpretations of sustainability were found, and many teachers reported they were uncertain of its meaning [4]. Most teachers saw sustainability issues solely as knowledge problems, often altogether disregarding the social, ethical, personal, and economical aspects of sustainability. In doing so, they almost exclusively focused on the scientific facts and models behind sustainability issues.

In other studies, this omission of the citizen aspects of sustainability teaching has been found as well [13]. Traditionally, science education focused on the environmental aspects of sustainability (i.e., processes of climate change, toxicity of compounds, energy efficiency of different fuels). Only $15 \%$ of the 123 pre-service teachers that filled in a questionnaire on sustainable development used a combination of the people, planet and prosperity elements, whereas three quarters of the participants named planet aspects to be central to sustainability. This oversimplified understanding of sustainability is widespread, with a holistic view of sustainability often being absent [14]. Findings like these prompt researchers to call for a broader focus on multiple perspectives, critical thinking, added complexity, and socialization or repoliticizing sustainability issues in the classroom, of course combined with rational and scientific ways of thinking [15].

Recently, a review study has been carried out looking into pre- and in-service-teachers' perceptions of EC [16]. From these mostly quantitative studies, the researchers concluded that teachers adopt relatively narrow definitions of EC, focusing on local scale issues, the individual dimension of EC and remaining in the private sphere. The researchers conclude that these perceptions influence educational practice, and are thus worth looking into.

These studies are all based on quantitative data. A qualitative view on science teachers' understanding of sustainability is desirable. With this, we could better describe their rationale behind their interpretation of the complex and multifaceted concepts of sustainability and EC. This could provide a stronger foundation from which to support science teachers during teaching EC.

\subsection{Current EC Teaching Practice}

Several themes can be identified about current EC classroom practice. In recent years, a shift from EE towards ESD has been observed in science education policy documents $[14,17]$. Some researchers criticize this shift in focus, expecting this to be counterproductive for the transition towards a sustainable society [11]. However, despite this shift in policy focus, classroom practice seems as of now unaffected. While EE focuses strongly on ecocentrism, ESD introduces anthropocentric tendencies. Findings from a large, international comparison study show that science teachers in developing countries mostly adopt anthropocentric views, whereas ecocentric views still prevail among teachers in developed countries [4,18].

Zooming in on the Netherlands, the Dutch curriculum for lower secondary science education [19] (Kerndoelen 'Mens en natuur', core aims 'Humanity and nature', p. 10) does not explicitly mention EC or citizenship. It does, however, refer to citizenship aspects such as making informed decisions and behaving in a sustainable manner. Perhaps this relative under-represented role of citizenship in the Dutch curriculum has led to relatively poor results for the country in international comparison studies such as the International Civic and Citizenship Education Study [20].

Concerning sustainability, ESD, EE, and EfS, the Dutch lower secondary curriculum aims contain many examples, such as, for instance, "The student learns that people, animals and plants are in connection with each other and their surroundings (environment), and that technological and scientific applications affect the sustainable quality of these surroundings in both positive and negative ways" [19] (core aim 30, p. 11). In the 
Netherlands, the lower secondary curriculum aims form a set of guidelines; it is not an obligatory rulebook. This means that in the end, the teachers are the ones who decide what curriculum aims are pursued. From previous studies it became clear that not all science teachers think ESD is important [4]. Furthermore, teachers from different subjects show different willingness to teach ESD [4]. Therefore, to better understand the current state of EC teaching in the Netherlands, it is necessary to look into the choices teachers make and their rationale behind those decisions.

Next to the national curriculum, teachers formulate their own learning aims for students. In ESD, three different approaches to learning aims have been defined by Kelly [21]: (i) a focus on science theory, discarding emotional aspects entirely to prevent indoctrinating students with their own opinions; (ii) raising awareness of environmental issues; and (iii) showing the complexity and controversial nature of sustainability issues with the aim to promote responsible decision making. Reasons for picking the first strategy commonly include the focus of national exams on theory, a focus that creates the risk of painting too narrow a picture of sustainability issues [15]. Neglecting or glossing over negative emotions in sustainability debates has been deemed a common and undesirable trait of current science education practice [22]. Exploring teacher-initiated learning aims related to sustainability could further improve our understanding of current EC practice.

\subsection{Challenges of Teaching EC}

Previous studies have found a diverse range of challenges with teaching EC at the lower secondary level. A review study on teaching EfS shows that secondary teachers generally feel they lack skills to effectively integrate it into their regular classroom practice [12]. Teachers say they are used to teaching scientific facts, whereas they are uncertain with teaching ethical and social issues in the science classroom [23]. Because sustainability issues are often controversial in nature, they benefit strongly from teaching methods that involve discussion and dialogue, yet science teachers feel less secure in applying these activities [13].

Another main issue for science teachers is the multidisciplinary character of sustainability issues. This complicates teaching because many teachers come from highly specialized backgrounds. Interdisciplinary teaching would enable students to develop EC competences, whereas focusing on individual topics is counterproductive to reach EC [14]. Teaching about sustainability in a holistic manner, thus showing interconnectedness of topics, makes EfS difficult [24]. Next to holism, pluralism is important when teaching about sustainability issues. In a pluralistic classroom, multiple perspectives on issues are considered. Pluralism, like holism, has been found to be hard for science teachers [25].

Other, more practical, complicating factors for teaching sustainability were found in the previously mentioned study by Borg and colleagues [4]. In this study, teachers reported that teaching sustainability issues was made difficult by a lack of time and space in the curriculum, a lack of inspiring examples, a lack of time to adapt existing teaching activities to make them more suitable, and a lack of perception of learning aims for sustainability education. Similar conclusions are drawn in other studies, e.g., [12].

As can be seen from many of these data sources, most of what we know about currentday science teachers and their views towards sustainability, their current EC teaching practice, and the challenges they experience with teaching EC stems from quantitative studies. A qualitative, in-depth view would improve our understanding of what support science teachers need when teaching these topics.

\section{Method}

For this study, 41 science teachers were interviewed in a face-to-face setting. The interviews lasted for $31 \mathrm{~min}$ on average. 


\subsection{Participants}

Teachers were approached from the researchers' network. Participants were selected to ensure a representative topographical spread, gender ratio, and subjects taught. Table 1 shows background data of the participants. The final sample slightly over-represented rural areas when considering the urbanization ratio of The Netherlands, which lies at $91.5 \%$, with $15 \%$ of the interviewed teachers being from rural areas [26].

Table 1. Background data of the interviewed teachers, showing age, gender, teaching experience, current subjects taught, and type of school (rural or urban).

\begin{tabular}{|c|c|}
\hline Category & Background Data \\
\hline Age & $\begin{array}{l}\text { Average: } 44.2 \\
\text { Minimum: } 25 \\
\text { Maximum: } 64 \\
\text { 20-29: } 9 \\
\text { 30-39: } 7 \\
\text { 40-49: } 8 \\
\text { 50-59: } 11 \\
60 \text { and above: } 6\end{array}$ \\
\hline Teaching experience (years) & $\begin{array}{c}\text { Average: } 11.9 \\
\text { Minimum: } 1 \\
\text { Maximum: } 40 \\
\text { 0-9: } 19 \\
\text { 10-19: } 18 \\
\text { 20-29: } 1 \\
\text { 30 and above: } 3\end{array}$ \\
\hline Gender & $\begin{array}{c}\text { Female: } 19 \\
\text { Male: } 22\end{array}$ \\
\hline Current subjects taught (number of teachers) & $\begin{array}{l}\text { Biology: } 26 \\
\text { NASK }^{1}: 16 \\
\text { Science }^{2}: 6 \\
\text { Other }^{3}: 19\end{array}$ \\
\hline Urbanization level of school area (number of teachers) ${ }^{4}$ & $\begin{array}{l}\text { Rural: } 6 \\
\text { Urban: } 35\end{array}$ \\
\hline
\end{tabular}

${ }^{1}$ Abbreviation of Natuur-scheikunde (Physics and chemistry), a subject that some schools teach at the lower secondary level. ${ }^{2}$ Some schools teach this subject, which focuses on scientific inquiry through problem-based learning and question-oriented learning. ${ }^{3}$ Other subjects include mathematics, home economics, IT, and researchbased subjects. ${ }^{4}$ Based on number of addresses per $500 \mathrm{~m}^{2}$.

\subsection{Instruments and Data Collection}

A semi-structured interview approach was used to gather the data (for interview scheme see Supplementary Material, available online). The interview scheme was constructed to cover a broad range of teacher activities, including their conceptual understanding of sustainability and citizenship, whether they think it is important for their teaching practice, learning aims, lesson design, and carrying out EC lessons in the classroom. Furthermore, to explore their aims and teaching approaches with EC, we asked them in what way they recognized EC concepts in the national curriculum aims. After this, we asked them about challenges they experience with applying EC in the classroom, and their levels of confidence when teaching EC. To fortify our understanding of their confidence with teaching EC, the interview ended with questions regarding incorporation of other socioscientific issues in their lessons, and three self-efficacy questions. The self-efficacy questions were based on the three self-efficacy themes defined by Tschannen-Moran and Woolfolk Hoy [27]: (i) classroom management, (ii) ability to motivate students, and (iii) availability of teaching and learning activities, all seen from an EC angle. 


\subsection{Data Analysis}

All interviews were audio recorded and transcribed verbatim, omitting vocalized pauses to enhance readability of the transcripts. Common themes were sought in the transcripts based on the constant comparative method [28]. This method consists of several cycles of coding all the transcripts, with each cycle further specifying and tightening the coding scheme. During the first cycle of coding, the data are coded in as many categories as necessary. Notes about emerging themes were made, which informed subsequent cycles. During these following cycles, the coding scheme was narrowed down, ultimately leading to a tight, cohesive set of codes that shows common themes in the data (see Supplementary Material, available online, for the final list of categories and their descriptions). A second researcher coded $12 \%$ (five interviews) of the data using the developed coding scheme, and after discussing the two analyses, $98 \%$ of agreement was reached. This indicates nearly perfect agreement [29]. Percentage of agreement is an applicable intercoder reliability measure in this case because in the current study, each code can be given only once to each teacher [29]. Based on the discussion, the coding scheme was finalized and the whole dataset was coded accordingly.

\section{Results}

The following common themes were found after analysis of the science teacher interviews.

\subsection{Science Teacher Definitions of Sustainability and Citizenship}

When teachers described their definition of sustainability, planet aspects were by far the most common of the triple bottom line, with about half of the teachers' answers falling in that category (19/41, Figure 1). In contrast, prosperity aspects were mentioned by less than one tenth of the teachers $(3 / 41)$. One teacher summarizes:

"Well, kind of, reuse of resources. Good for the environment, little $\mathrm{CO}_{2}$ emissions. Yes, something like that? It is kind of a vague concept, isn't it? Students think so too, by the way."

(Teacher 11)

A few teachers give a definition of sustainability that fits closely to the Brundtland definition (7/41). Most teachers focus on sustainable processes and recycling when defining sustainability instead (24). About half of the teacher definitions of sustainability included references to the environment (22/41) and prolonged use of products and materials (18/41). Another common theme is effects on next generations (12/41). As the following quote illustrates, 13 teachers mentioned sustainability is a container concept:

"Sustainability concerns, it is a very broad concept, a container concept that contains a great many things. Sustainability is about for instance sustainable energy. It is about all kinds of resources that nature offers us, and using these in a sustainable manner. So using them in such a way that we can use them again. Kind of. It is about leaving a sort of Earth that can be used again. On which you do not exhaust all kinds of resources, but with which you, where you can use them but use them in such a way that next generations can use them too. Kind of a vague story, but. And then you can talk about solar energy, well, apart from the materials where that is made out of, what do you do with that?"

(Teacher 23) 


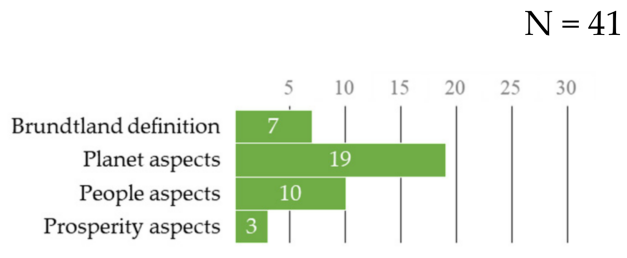

Categories per teacher: 2.1

\section{How would you define citizenship?}

Categories per teacher: 3.0
How would you define sustainability?

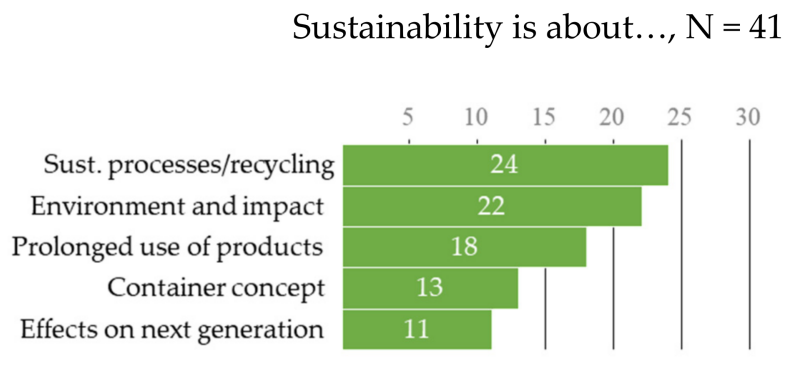

(a)

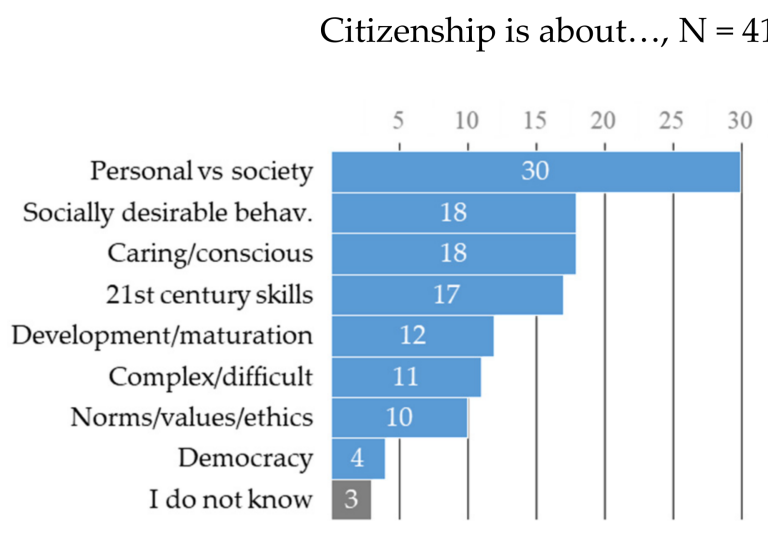

(b)

Figure 1. Definitions of: (a) sustainability, including categorization on Brundtland and triple bottom line of sustainability (people, planet, prosperity); and (b) citizenship, according to the 41 interviewed teachers. Numbers in the bar graphs represent total number of teachers whose answers fell in the respective categories.

Concerning citizenship, three quarters of the teachers define it using terms that describe the relationship between the personal, the individual, with society $(30 / 41)$. According to half of the teachers, citizenship deals with socially desirable behavior (18/41), caring for your surroundings, being involved and conscious about your place in society $(18 / 41)$. One teacher says:

"I find that a very difficult question, but yeah, I see that as learning from each other, how you find your way in this society and, how you develop, in such a way that you add something to society and your surroundings and people around you, and that can be very broad but it can also be very small, in a smaller circle. Yes, summarizing, adding something to your surroundings."

(Teacher 39)

Citizenship is seen as being part of 21st century skills by seventeen teachers. A quarter of the teachers says it has to do with the development or maturation of the students $(12 / 41)$ and with norms, values and ethics (10/41). A total of 11 teachers think citizenship is a complex and difficult concept, with three other teachers going further by claiming they do not know how to define it at all.

\subsection{Curriculum and Classroom Practice}

Twenty-five teachers think there is a lack of sustainability in the national curriculum (Figure 2). They think the curriculum overemphasizes the theoretical side of sustainability $(12 / 41)$ and that sustainability is incorrectly represented in the current curriculum (9/41). Describing this, one teacher says:

"The disadvantage of school is you have a program, [ . . ] with physics lessons, sustainability isn't at all an item there. But as soon as we discuss solar panels and solar energy, 
then suddenly it is. So I think it is an important theme, but I could do a lot more about it. [ ... ] Because learning is not only for your test or the exams, it is also life-learning. [...] You don't always have the time for that, [ ... ] not the societal part, and that is a pity, it only is the technical aspect [... ] Look, that whole discussion now, about, we have a climate treaty [... ] And then the question immediately presents itself: how are we going to make that workable? What can we do with it? That whole kind of thinking, look, students know very little about that."

(Teacher 34)

\section{Do you recognize sustainability in the national curriculum?}

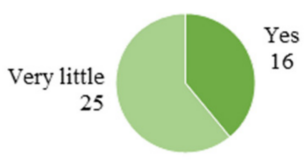

Categories per teacher: 1.0

\section{Do you think sustainability is important for your lessons?}

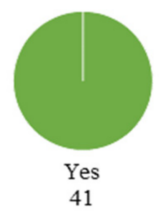

Categories per teacher: 1.2

\section{Do you incorporate sustainability in your lessons?}

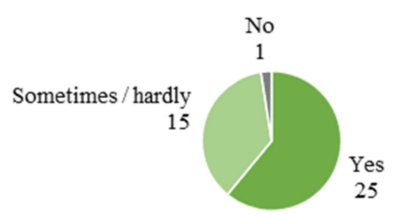

Categories per teacher: 1.5 (b)

Further comments, $\mathrm{N}=41$

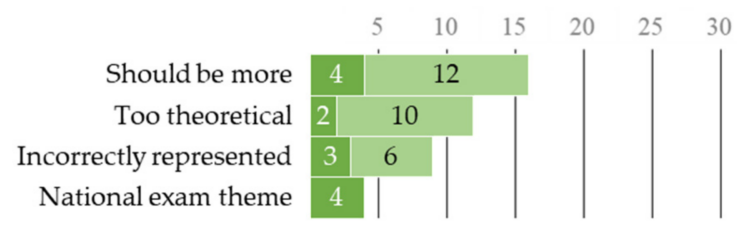

(a)

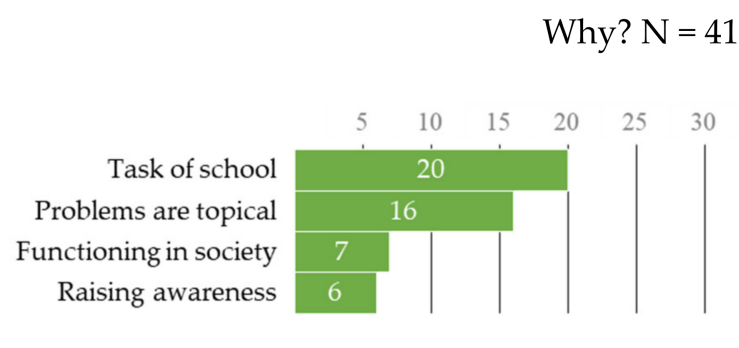

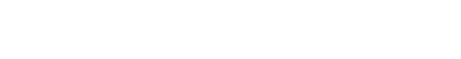

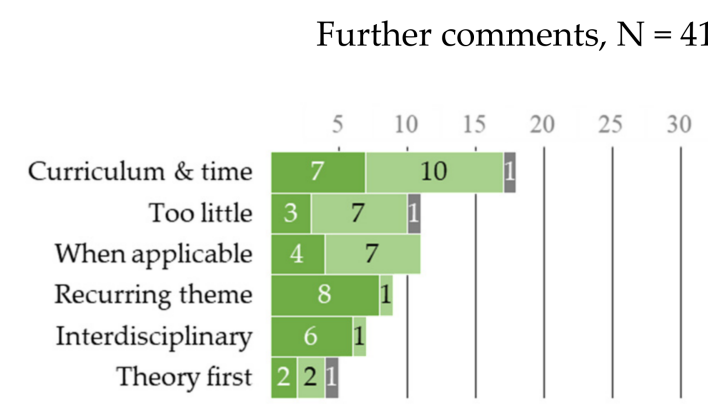

(c)

Figure 2. Teacher perceived (a) curriculum presence, (b) importance in the classroom, and (c) teaching occurrence of sustainability, as described by the 41 interviewed teachers. Numbers in the bar graph represent total number of teachers whose answers fell in the respective categories. Colors in the pie and bar graphs correspond. 
Despite this general lack of sustainability in the curriculum, all interviewed teachers think sustainability is important for their lessons. Twenty teachers feel that it is a task of the school to teach about sustainability. Sustainability issues are typified as urgent and topical $(16 / 41)$, so they should be taught at school. Seven teachers think that students need to know about sustainability to function in society. One teacher explains:

"I think it is a very important theme, because you see it a lot around you of course. [ ... I You see it everywhere, this is sustainable, that is sustainable, on fashion brands, or sustainable wood, you know, on these stickers and labels, you find them all the time. I think it is important that we pay attention to this during biology lessons, because it kind of is a term that is used regardless of whether it is appropriate or not, even though it is kind of a difficult concept. What actually is that, sustainable? [ . . ] Where does the sustainability come from then? I think it is a subject, certainly for biology and mainly in lower secondary level, [ . . . ] that everyone should learn something about."

(Teacher 13)

Despite the criticism on the curriculum, over half of the teachers (25/41) incorporates sustainability in their lessons. Nine teachers claim it is a recurring theme for them. Reasons for only occasionally incorporating sustainability in their teaching include a lack of time and a full curriculum (11/41), and a focus on theoretical subject knowledge first for the lower secondary level, before more complex topics such as sustainability can be taught in the higher secondary level (4/41). This is illustrated by one of the teachers, saying:

"Currently on my schedule is sustainable energy. We discuss energy use, gas and electricity, energy at home, energy transport, [ . . ] and at a certain moment you discuss how do you produce electricity? Yeah, you don't just discuss coal plants then, but you also have to explain wind turbines and discuss the energy transition and explain that. I think this belongs in the curriculum. Next to that, you hope that children learn more than what is written in the textbook, but that they become kind of critical citizens of the world, in a way, and that, that is kind of a side effect that I hope to achieve in my lessons, but it is not part of the program. And I try to stimulate them and because I like this subject I talk about it sometimes, but I do not always receive the response that I like. Then I think yeah we have subjects such as philosophy and big thinkers, let them discuss these themes there as well. And I think that this belongs there more, and in chemistry, I think, yeah you should discuss plastics and recycling and such, the actual content belongs here, but the moral stuff belongs on a higher level."

(Teacher 12)

Only one teacher says they never teach about sustainability, with reasons for this including the curriculum and this focus on theory first.

In contrast, about half of the teachers do not recognize any citizenship in the national curriculum (18/41, Figure 3), with a further quarter of them only seeing very little citizenship in the curriculum (12/41). Elements of citizenship that are there are connected to sustainability (10/41) or related to opinion forming (10/41). Eight teachers feel there should be more citizenship in the science curriculum, and seven teachers feel citizenship is mainly connected to other subjects or should be mainly taught at the school level. One teacher says:

"I think there is nothing about it [citizenship] in there [the curriculum]. I cannot remember at least. I should have a look at that, if there is something in the chemistry curriculum about citizenship. But I cannot remember it being there. [ . . . ] Actually, I would be surprised if it is there, very honestly. But in a way I would think it is good if it is there, because I think chemistry plays a role in that too. [ . . ] But I think it is kind of limited, because it actually only fits with sustainability, because all other subjects [ . . . I I could not think of another subject that could fit with it [ . . ] polymers perhaps, plastics, but those again connect to sustainability. So all of it is sustainability related then."

(Teacher 8) 


\section{Do you recognize citizenship in the} national curriculum?

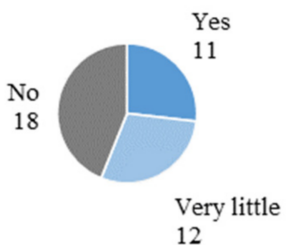

Categories per teacher: 1.6
Further comments, $\mathrm{N}=41$

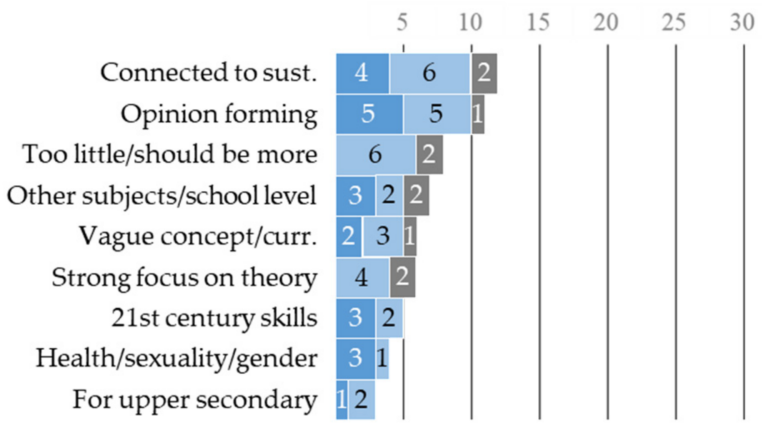

(a)

\section{Do you think citizenship is important for} your lessons?

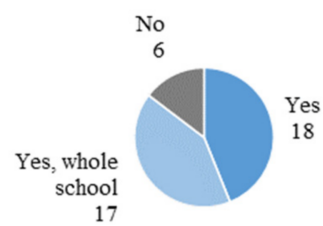

Categories per teacher: 1.7

\section{Do you incorporate citizenship in your lessons?}

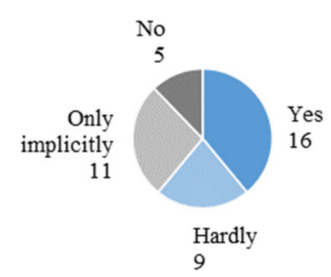

Categories per teacher: 2.8

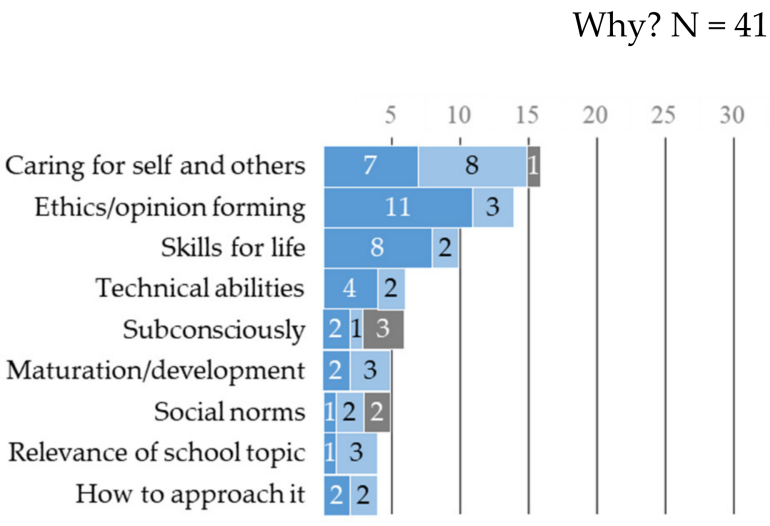

(b)

Further comments, $\mathrm{N}=41$

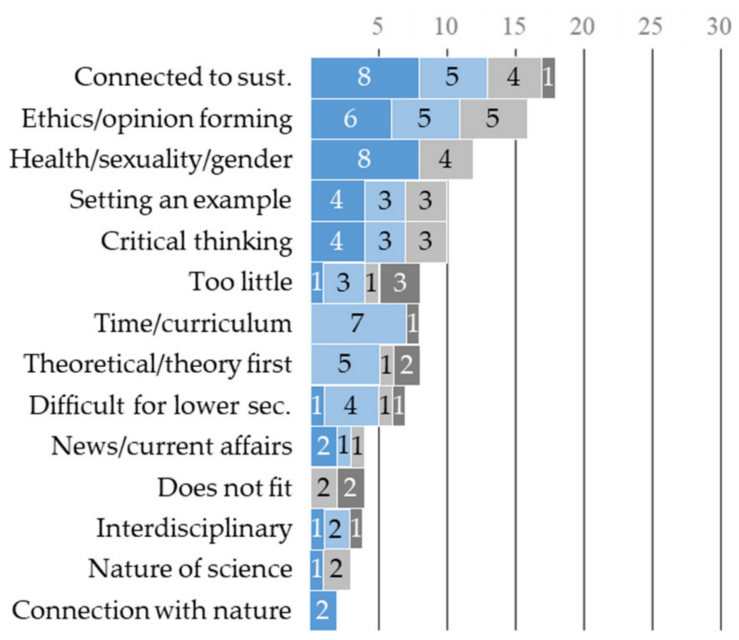

(c)

Figure 3. Teacher perceived (a) curriculum presence, (b) importance in the classroom, and (c) teaching occurrence of citizenship, as described by the 41 interviewed teachers. Numbers in the bar graph represent total number of teachers whose answers fell in the respective categories. Colors in the pie and bar graphs correspond.

As can be seen from Figure 3, some teachers say citizenship is a vague concept. Again, teachers describe the theoretical focus of the science curriculum, leaving little room 
for topics such as citizenship. Three teachers think that citizenship is more suitable for the upper secondary level.

Many teachers think citizenship is important for their lessons (18/41), while other teachers do agree with this, adding that it is important for all subjects $(17 / 41)$. Fourteen teachers think it is important because it is about care for oneself and for others. Other reasons include ethics and opinion forming being important (14/41) and citizenship being a necessary skill for life (10/41). Describing this in further detail, one teacher says:

"Yes I think indeed, students at school, they do not necessarily, do not see the use of lessons very often. Even though I think that when you show the use to yourself and of the world around you, without that, we cannot live. [ . . . I think we have an important societal role or responsibility as biology teachers. But [ ... ] I think that citizenship should be more prominent in that."

(Teacher 32)

Just under half of the teachers actually incorporate citizenship in their lessons (16/41), with a further nine claiming to do so hardly ever, and eleven others only doing so implicitly. Five teachers never teach citizenship at all. Time or room in the curriculum is seen as a limiting factor $(8 / 41)$. Teachers want to focus on theory first (8/41) and feel citizenship is too difficult for lower secondary level students $(7 / 41)$. Four teachers think it does not fit with their subject at all. In answering whether they incorporated elements of citizenship education in their lessons, one teacher says:

"No, not that much. Concerning this, chemistry is a very technical subject. You learn several things and you learn how you can deal with certain conditions but you do not learn how to prevent issues. And you learn how you can potentially solve issues, but critical thinking, would you do this or that, yeah, much, much less. Chemistry is a subject that is very much anchored in protocols and rules. You have the twelve principles of green chemistry, that concerns how you can use chemistry in a green manner, [ ... ] so, chemistry that is as sustainable as possible, that does lead to as little waste as possible. These are rules and formulas and you can in a way calculate [...] how green something is, how sustainable something is. With this, a critical view, that isn't at all a thing. You just do what is written down. You follow the recipe. Totally at the end, you could incorporate a critical view on, you have two processes, $a$ and $b$, and the end result is this and that. Compare the two and which one is the greenest? But yeah, is that critical? I don't think so. Because critical thinking means you make your own judgement, and think about it yourself, and reason about stuff, and that happens very little, [ ... ] yeah that isn't a thing at all."

(Teacher 10)

Reasons given for incorporating citizenship in science education include its connection to sustainability (17/41), or to ethics and opinion forming (16/41) and because citizenship connects to many issues about health, sexuality and gender (12/41). Ten teachers aim to set an example for their students and stimulate critical thinking, both of which are perceived to be elements of citizenship in their classroom practice.

\subsection{Teaching and Learning Activities and Learning Aims}

Teaching and learning activities that teachers deem suitable for sustainability issues vary greatly (Figure 4). About two fifths of the teachers use discussion, research, and videos or documentaries during teaching about sustainability. With these activities, over half of the teachers aim to raise awareness (24/41). Many teachers aim to show the impact of our behavior or to show the bigger picture (15/41). For a third of the teachers, opinion forming and decision making is an aim, so are teaching theory and 21st century skills. One teacher says: 


\section{What teaching and learning activities do you employ during sustainability education?}

Categories per teacher: 3.7

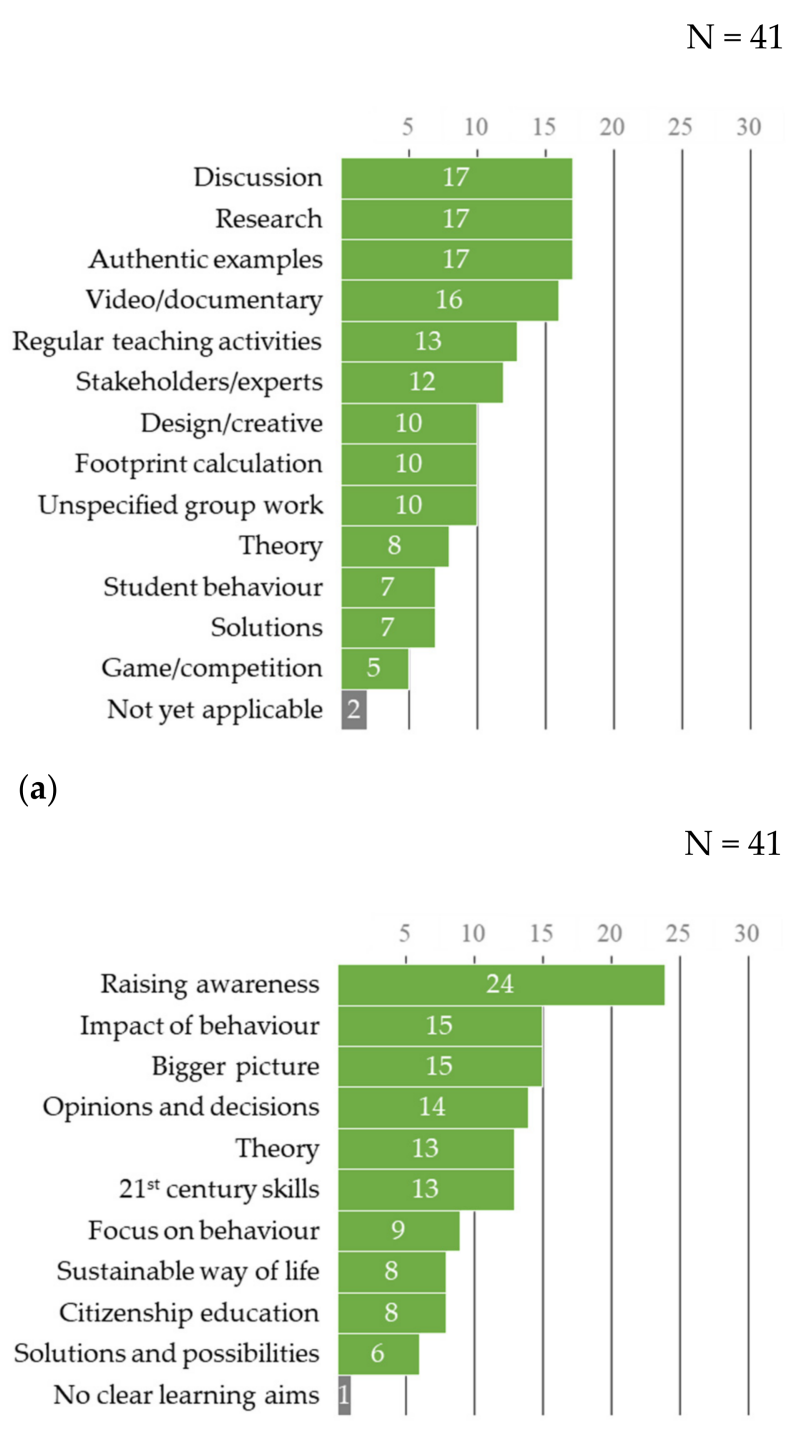

(b)

Figure 4. Sustainability (a) teaching and learning activities and (b) learning aims, employed by the 41 interviewed teachers. Numbers in the bar graph represent total number of teachers whose answers fell in the respective categories.

"You also want that, sometimes, that they can see there is a problem they cannot solve. That in itself is a very important learning aim, [ . . ], that they have to choose between multiple solutions none of which are the perfect solution. Well, such a soft learning aim, $[\ldots]$ that they see that this is an interdisciplinary problem, that you have to deal with many people, with different parties, yeah, and you can, depending on the topic or where you are in the curriculum, there are also sustainability concepts that you can have as learning aims, but I feel that, why I think it is important, that is because of the softer learning aims."

(Teacher 36)

Teaching and learning activities during citizenship education often feature discussion (13/42, Figure 5) and resemble regular teaching and learning activities (13/41). Ten teachers do not teach citizenship at all. Half of the teachers mention learning aims dealing with 21st century skills and opinion forming or decision making. One teacher explains: 


\section{What teaching and learning activities do you employ during citizenship education?}

Categories per teacher: 2.1

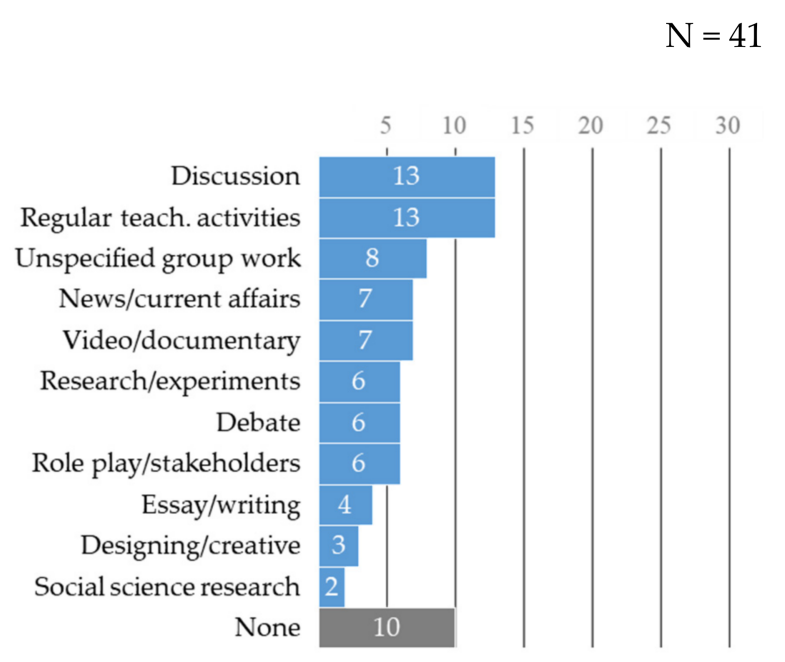

(a)

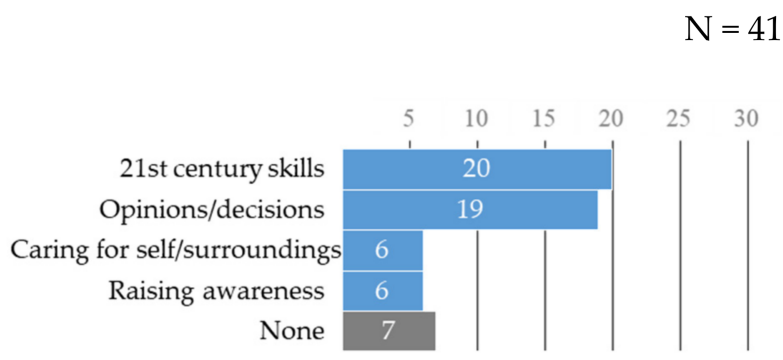

(b)

Figure 5. Citizenship (a) teaching and learning activities and (b) learning aims, employed by the 41 interviewed teachers. Numbers in the bar graph represent total number of teachers whose answers fell in the respective categories.

"Especially the development of an educational approach [ . . . ] in secondary education that is very underdeveloped. That I think is challenging [ . . ], I just mentioned complexity, there are a few competences that belong with that, right, [ . . ] such as systems thinking, but also future thinking, painting scenarios from the future. And, paying more attention to the moral aspects of issues, because, it isn't like something is right, something is wrong, desirable or undesirable, but by whom, etc., and what do you do with that? So I think developing a moral compass on that front is very important."

(Teacher 37)

\subsection{Challenges and Confidence with Sustainability and Citizenship in Science Education}

Fourteen teachers feel less confident about teaching sustainability than other topics (Figure 6). The most common reason for this is the different opinions that exist on the topic $(10 / 41)$. The other teachers do feel confident with teaching sustainability, with the most common reason being their inherent interest in the topic. Teachers are also able to come up with real life examples, often from their own surroundings. 
In relation to other topics, how confident are you with teaching about sustainability?

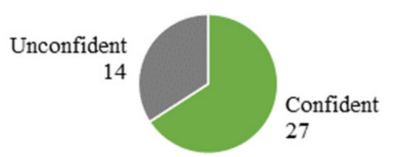

Categories per teacher: 1.1

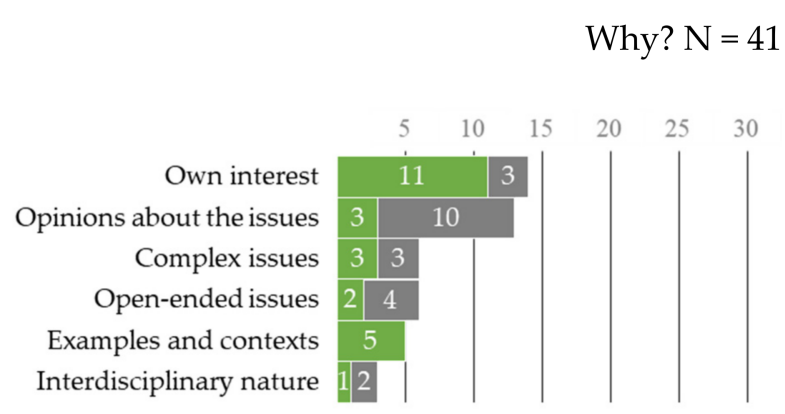

Interdisciplinary nature (a)

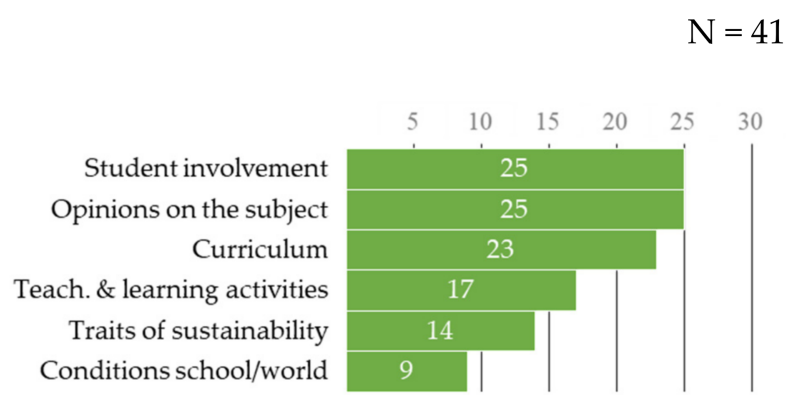

(b)

Figure 6. Teacher (a) confidence with and (b) challenges when teaching sustainability. Numbers in the bar graph represent total number of teachers whose answers fell in the respective categories. Colors in the pie and bar graphs correspond.

When asked to name the biggest challenges with teaching about sustainability, more than half of the teachers mention three main issues. The first one is difficulties with student involvement. Teachers think students are not interested in sustainability, or perceive it as something that is far off for the students, as this teacher describes:

"Maybe, when I think about it now, when I teach about these topics [sustainability], I experience an enormous distance between the world of the students, who do not at all look at it this globally, they only see their daily lives. I would almost say, they do not even look further than their own table, [ ... ] they do not see anything. And this is a global look on things, where you look at how do they do this for society at large [ ... ], and that distance is really big. And that way, I can only very difficultly connect with the world of the students. [ ... ] That truly is a field with opposing powers. That means I have to work really hard to accomplish something here."

(Teacher 16)

Equally as challenging are the many different opinions that exist among the students regarding sustainability. These opinions can sometimes be experienced as very harsh or strong, involving strong emotional responses. The third biggest challenge according to these teachers was the curriculum. It pays too little attention to sustainability, and it takes a too theoretical approach. Less common reasons include difficulty with finding suitable teaching and learning activities, and specific traits of sustainability issues making it less easy to implement, for instance, because issues are abstract and play on such a large scale. Nine teachers felt that conditions in the world or at school, for instance, dealing with colleagues who did not think sustainability was important, made teaching about sustainability challenging.

Science teachers seem to feel less confident about teaching citizenship, with half of them feeling confident (21/41), two fifths feeling less confident (14/41) and six saying they 
never implement citizenship at all (Figure 7). Teachers feel most unconfident about guiding discussions, followed by less common answers such as lack of prior knowledge, inexperience, and the necessity of preparation before teaching these lessons. One teacher explains: In relation to other topics, how confident
are you with teaching about citizenship?

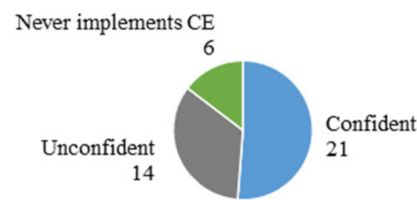

Categories per teacher: 0.9

\section{What challenges are related to teaching about citizenship?}

Categories per teacher: 2.0

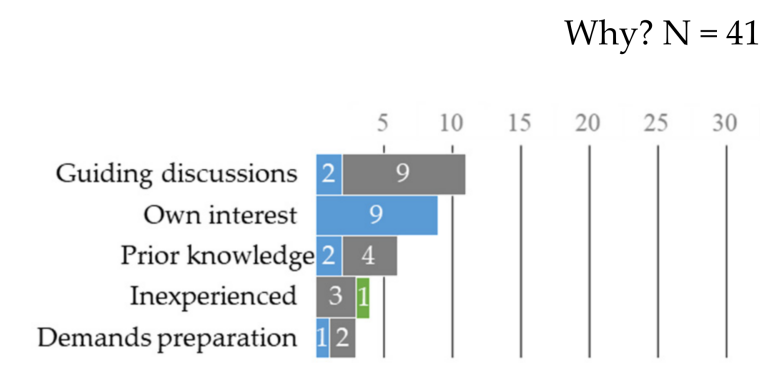

Why? $\mathrm{N}=41$

(a)

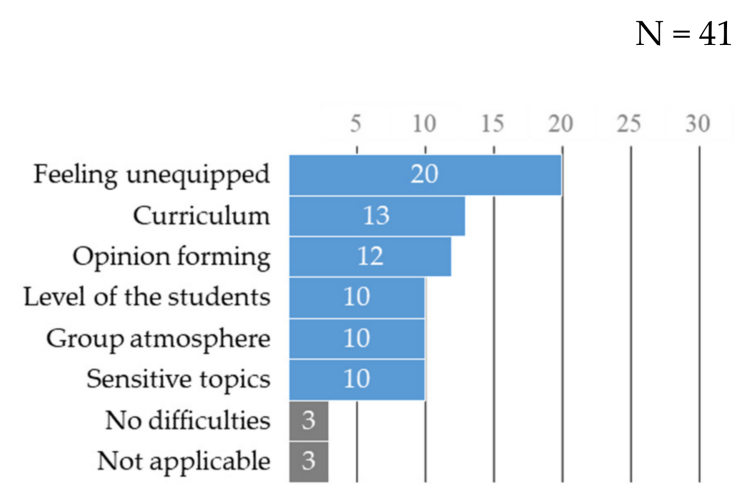

(b)

Figure 7. Teacher (a) confidence with and (b) challenges when teaching citizenship. Numbers in the bar graph represent total number of teachers whose answers fell in the respective categories. Colors in the pie and bar graphs correspond.

"Maybe I feel more confident with other topics, because those are of course mainly theoretical. When you tell how to name a molecule. Yeah, there is little discussion possible about that. But when you talk about sustainability, then... I think I am also a little less trained for that. So, yes, I think I am a little bit more unconfident the moment I talk about sustainability, also because more discussion can arise then, you can never exactly know what might happen."

(Teacher 8)

Eleven teachers are confident because they are interested in citizenship aspects of their subject.

The most common challenge for science teachers with integrating citizenship education in their lessons is that they feel unequipped to teach citizenship (20/41) - for instance, because of difficulty with guiding discussions and being unsure about assessment and evaluation of citizenship. One teacher says:

"I think it is difficult for instance to guide a discussion. [ ... ] That is not something I am trained to do, and I know that other teachers are way better at this, so I try to avoid it a little bit. And that does make me feel a little insecure. [ ... ] And I think it is difficult to gain insight in student opinions. Because it usually are the same students who quickly form an opinion. [ ... ] To make them say what they feel, their opinion, that is pretty difficult. [...] And the fact alone that I do not really know what citizenship education means, that tells you something about how confident I am about this. [ . . . It is a very vague concept. [ ... ] And I also do not know when it is good enough or something. With 
sustainability you can just show some examples, but with citizenship, I just don't know when I have sufficiently reached these students. [ ... I It is way easier to set learning aims for sustainability than for citizenship education."

(Teacher 7)

Other common themes that create challenges are the curriculum, difficulty with external influences on opinion forming, such as parents or politicians. Finally, teachers say an experienced lack of cognitive level of the students is challenging, as well as creating the right atmosphere in the group, and difficulties with sensitivity of citizenship topics. Three teachers do not experience any difficulties whatsoever with citizenship.

\subsection{Sustainability and Citizenship and Other Socio-Scientific Issues in Science Education}

All science teachers agree that the combination of sustainability and citizenship is logical (Figure 8). Reasons for this include both of these topics concerning making choices or decisions and involving social and societal aspects.

\section{Would you say the combination of sustainability and citizenship is logical?}

Categories per teacher: 1.2
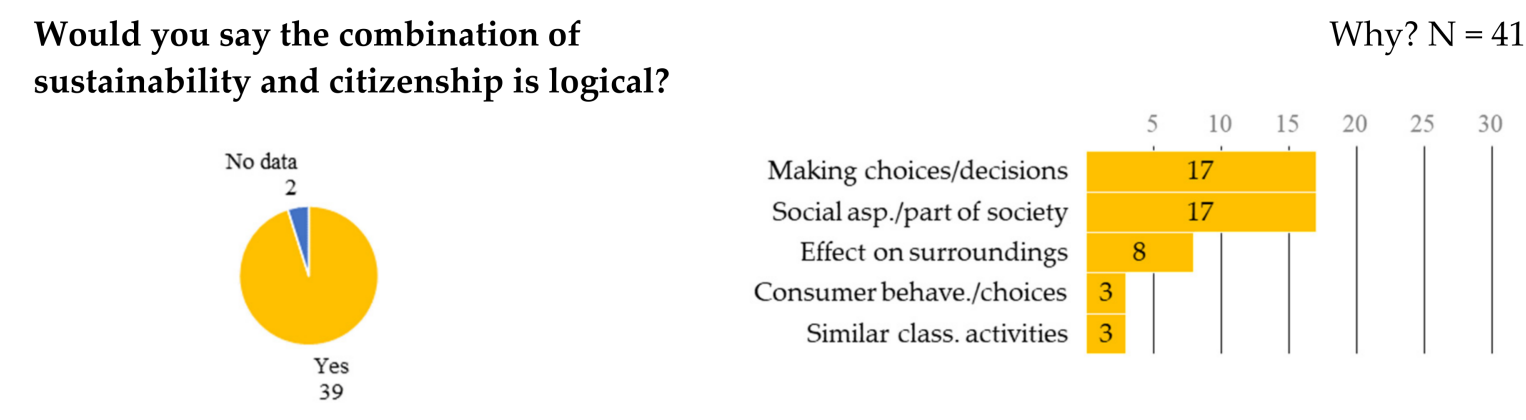

Why? $\mathrm{N}=41$

(a)

\section{Do you incorporate other socio-scientific issues than those related to sustainability in the classroom?}

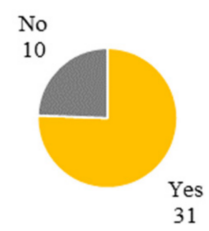

Categories per teacher: 2.4

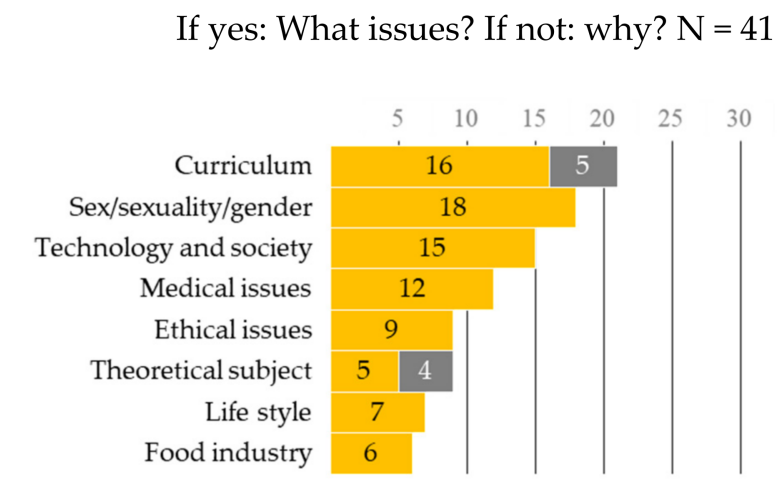

(b)

Figure 8. Comments on (a) the combination of sustainability and citizenship, and (b) use of nonsustainability related socio-scientific issues in the classroom, according to the 41 interviewed teachers. Numbers in the bar graph represent total number of teachers whose answers fell in the respective categories. Colors in the pie and bar graphs correspond.

A total of 31 teachers incorporate societal issues other than those related to sustainability in their teaching. The most common issues relate to sex, sexuality and gender (18/41), the relationship between technology and society, for instance with genetic modification or radioactive energy (15/41), and medical issues, for instance related to genetic screening $(12 / 41)$. All ten teachers who did not incorporate societal issues besides those dealing with sustainability were chemistry teachers. No biology teachers or teachers who taught both biology and chemistry fell in this category. Reasons for not teaching about issues other than sustainability related ones include no such issues being present in the curriculum (5/41) 
and the subject being heavily focused on theory (4/41). Only one of the teachers mentioned evolution as a societal issue about which they teach that is unrelated to sustainability (Teacher 29).

3.6. Self-Efficacy: Classroom Management, Student Motivation, and Availability of Teaching and Learning Aims

Teacher self-efficacy aspects related to EC varied. A total of 27 teachers think classroom management is at least a little harder when teaching about sustainability and citizenship education then other subjects (Figure 9). Reasons for this are that discussion and opinions are difficult to manage (19/41), and that creating a safe classroom atmosphere costs effort.

\section{Compared to other topics, how easy is classroom management during sustainability and citizenship education?}

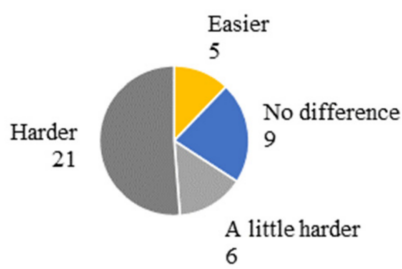

Categories per teacher: 2.0

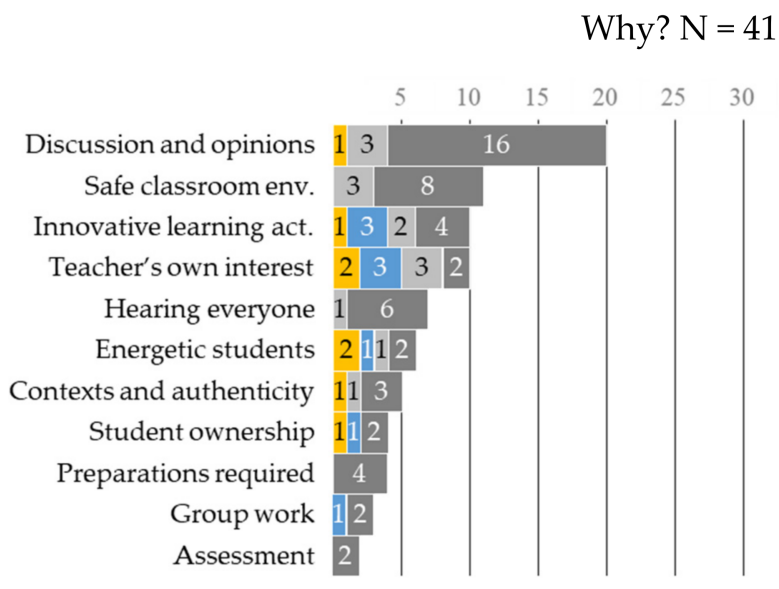

(a)
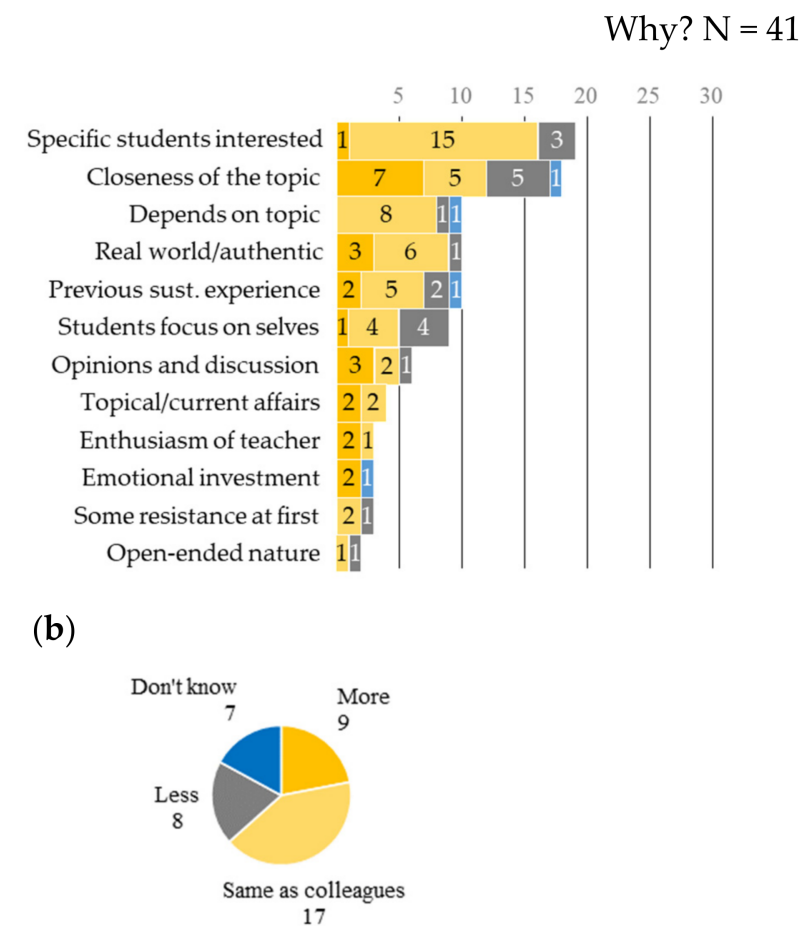

(b)

(c)
Compared to your colleagues, how many teaching and learning activities do you use during sustainability and citizenship education?

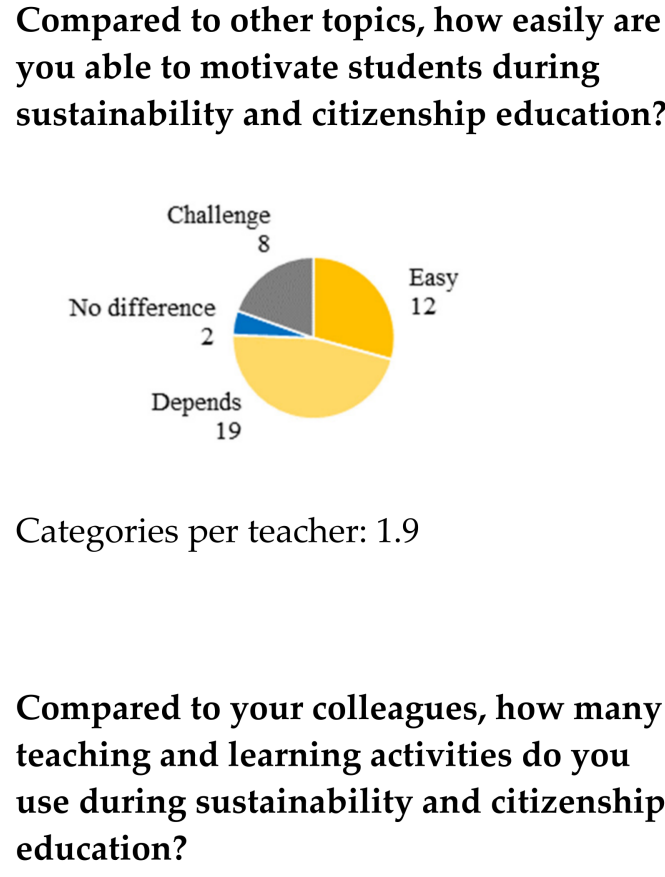

Compared to other topics, how easily are you able to motivate students during

(b)

\section{)}

Figure 9. Self-efficacy elements: (a) classroom management, (b) student involvement, and (c) number of available teaching and learning activities related to EC education, according to the 41 interviewed teachers. Numbers in the bar graph represent total number of teachers whose answers fell in the respective categories. Colors in the pie and bar graphs correspond. 
$(11 / 41)$. Five teachers think that classroom management is easier for these topics. This is mainly caused by the teachers' own interest in these fields, innovative teaching activities, and energetic students. The nine teachers that did not see any difference in classroom management mainly said that learning activities are innovative, but this was something they liked.

According to nineteen teachers it is not easy to say whether students are more easily motivated during sustainability or citizenship education compared to other topics, whereas twelve teachers think it is easier to motivate them. Eight teachers think motivating students for sustainability is a challenge. Inhibitors for student motivation are students being focused on themselves at this age $(8 / 41)$, and students being tired of sustainability because they hear it everywhere $(8 / 41)$. One teacher says:

\begin{abstract}
"That differs strongly per topic, because I see that these kind of teaching and learning activities, sometimes they work brilliantly, but I think that depends strongly on the topic and not on the activity. For instance with sustainability, that is really trending right now, and if you discuss that now, depending on how you do it by the way, because when you only talk about theory that they already know than they don't care at all, but because it is a very trendy topic they want to talk about it for sure, but for instance, at a certain point things such as bio-industry they have hear about this so many times, they don't want to hear about it anymore."
\end{abstract}

(Teacher 5)

Motivation strongly depends on the type of student, with specific students being more interested in these topics (19/41), and on the sustainability issue or citizenship aspect that is discussed (10/41). Teachers do not agree whether sustainability and citizenship issues are topics that are close to the student world, with about equal quantities claiming these issues to be close $(7 / 41)$ and far removed from the student's world $(5 / 41)$. The twelve teachers who think students are easily motivated for sustainability and citizenship teaching think this is caused by the opinion forming activities (3/41) and the authentic nature of the issues (3/41), among others.

A total of 26 teachers felt they had at least equally as many teaching and learning activities at their disposal for teaching about sustainability and citizenship as their direct colleagues. Eight teachers thought they could incorporate less teaching and learning activities than their colleagues for this type of teaching, and a further seven were unable to judge this.

\title{
4. Discussion
}

In order to better support science teachers when teaching EC, we need a better understanding of current EC practice, and teacher interpretations of EC. Based on the findings from this study, current EC practice among the interviewed teachers seems as diverse as the concept itself.

\subsection{Definitions}

Teacher definitions of sustainability most commonly revolve around planet aspects. These teachers mostly focus on the environmental side, with only seven teachers using a full sustainability view, based on the Brundtland definition. This finding corresponds with previously reported findings in the literature [16,30]. It thus seems that Kopnina's [11] criticism regarding the shift from EE to ESD does not yet manifest itself in Dutch science teachers with highly economic or societal ideas about sustainability. Most teachers still seem to use an environmental approach [16]. This is further cemented by the most popular connotations of sustainability being impact on the environment, using products for prolonged times and sustainable processes regarding energy use and production efficiency in general. As a side note, many teachers believe sustainability is a container concept, so they might hint at it being broader than a purely environmentalist view.

According to the teachers, citizenship relates to the relationship between a person and society, with socially desirable behavior, and being active and caring for your surroundings. 
To many teachers, citizenship can be seen as a 21st century skill. These definitions most strongly show aspects of Westheimer and Kahne's [8] personally responsible citizenship, with some occasional signs of participatory citizenship. Personally responsible citizenship, while important, is not the only ingredient for a more socially just and sustainable world [31]. Aspects from social-justice-oriented citizenship, which most strongly relates to EC, are not seen in these teacher definitions of citizenship.

Based on these teacher definitions, it would be overly optimistic to assume that EC is effectively incorporated in science lessons of these teachers. Many teachers use a strong focus on recycling and small, at-home behaviors in their explanation of sustainability, which leads to an oversimplified view on how to solve sustainability issues in the long run. For this, a broader approach that also includes governmental or other collective actions is pivotal [32]. Teachers who do not include public-sphere behavior and the global aspects of EC that are necessary to reach a sustainable future in their EC teaching is a common theme in literature [33]. Our study adds to this knowledge base.

\subsection{Curriculum Presence, Importance and Classroom Occurrence}

Whereas all interviewed teachers think sustainability is important, only just over half of them clearly state they incorporate it in their teaching. The national curriculum seems a limiting factor here, as previously found in the literature [12], because teachers hardly recognize sustainability in the curriculum, and they are critical towards its overly theoretical representation. Citizenship education is even less common, with only one quarter of the teachers recognizing more than a little citizenship in the science curriculum. Just like with sustainability, a majority of teachers thinks citizenship is important, but this does not translate to classroom practice, with just under half of them clearly stating they incorporate it in their teaching. For these two concepts, it becomes clear that teachers are unable to put their views into practice.

The interviewed teachers' learning aims for EC mostly fall in the second and third categories of Kelly's [21] framework, these being raising awareness and promoting responsible decision-making. Only a quarter of the teachers mention learning aims dealing with theory behind sustainability, which would fall into Kelly's first category. The general lack of this learning aim contrasts with the strong theoretical bias that teachers experience with sustainability in the curriculum. It thus seems there is a mismatch between the theoretical approach of the Dutch curriculum and the learning aims of the teachers when sustainability issues are concerned.

Just like with the teacher definitions, the citizenship learning aims further strengthen the idea that Dutch science teachers adopt Westheimer and Kahne's [8] personally responsible and participatory views on citizenship, while largely ignoring the social-justice oriented citizenship which is necessary for true EC. This social-justice-oriented citizenship correlates strongly with EC's aim of public sphere, collective action taking, which could lead to fundamental changes in existing unsustainable structures and processes. Judging by their learning aims for EC, changing these existing structures seems to be beyond the scope of what science teachers in the Netherlands want to reach with their EC education at the lower secondary level.

\subsection{Confidence and Challenges}

Teacher confidence with, and challenges during, EC education found in this study add to the existing research base. The teachers most commonly identify opinion forming activities and guiding dialogue as challenging. These results are in line with previous studies which showed that science teachers generally struggle with implementing humanitiesbased teaching activities [23]. Finding a way to deal with student opinions during EC is the third most common element that lowers confidence of the interviewed teachers. They identified strong emotional responses of the students as challenging during sustainability and citizenship education. Previous studies link this to the value-laden character of EfS [12]. Many science teachers feel unequipped to teach citizenship in their science 
lessons, which mirrors findings from a large qualitative study with Swedish teachers [4]. Interestingly, the commonly reported difficulties with examination of EC [12] are only sporadically mentioned by the interviewed teachers.

Another common challenge for successful implementation of EC is the national curriculum. Teachers feel there is too little time for EC education in everyday practice. Furthermore, the curriculum is believed to misinterpret sustainability because it focuses too strongly on theory. Previous studies show that the curriculum is one of the biggest hurdles for teaching about sustainability issues [4,12], and socio-scientific-based education [34].

Common with sustainability thinking is a general feeling of hopelessness on the one hand, caused by the idea that it already is too late to turn the tide [22]. On the other hand, people might underestimate sustainability issues because effects of sustainability issues are often not felt close to home, which results in feelings of apathy and resignation [24]. Dealing with this emotional duality is difficult for teachers [22]. They feel that some of their students are unmotivated towards sustainability because students at the lower secondary level are focused strongly on their own developments and do not think about the world outside of their immediate surroundings. This shows in the data too, with about equal numbers of teachers thinking students can be easily motivated for sustainability, and teachers thinking that motivating students for these issues is a challenge.

Next to these challenges and uncertainties, a substantial group of the interviewed teachers is inherently interested in sustainability and citizenship. These teachers thus feel confident about teaching EC. Illustrating this, three quarters of the teachers incorporate other societal issues than those related to sustainability in their science lessons. All ten teachers who do not implement other societal issues in their lessons are chemistry teachers. It seems that biology teachers are more used to teaching about societal issues than their chemistry colleagues. However, such an indication needs to be subject to further research.

\subsection{Limitations}

When looking at the total science teacher population in the Netherlands, or, indeed, worldwide, this study only used a relatively small group of teachers. This should be taken into account when interpreting the results. Differences exist between countries, depending, for instance, on the curriculum or school system in general, so these data might only reflect the Dutch situation. Additionally, a general lack of teachers with more than twenty years of experience is seen among the participants. Finally, the participants slightly over-represent teachers from rural area schools, with urban schools being marginally under-represented. However, despite these limitations, this study still adds valuable qualitative data to the knowledge base about teaching EC at the lower secondary level, and it provides an in-depth sketch of the Dutch EC landscape.

\section{Conclusions}

When looking at EC education in the Netherlands, there seems to be a mismatch between the curriculum on the one hand, and the aims, ideas, and wishes of science teachers on the other. Despite a relatively narrow definition of sustainability and citizenship, Dutch science teachers aim to promote different aspects of EC through their teaching. Complicating this wish, teachers interpret the curriculum as being focused too strongly on theoretical aspects of EC, largely ignoring those areas that they wish to include. Furthermore, science teachers struggle with the social aspects of EC teaching, including dialogue, discussing emotions, and guiding opinion forming and decision making. Their understanding of EC does not yet involve many aspects of social-justice-oriented citizenship, and some teachers do not really see a place for citizenship education in science lessons at the lower secondary level at all. Additionally, teachers' views remain limited to the private sphere and to individual actions. However, what does become clear is that the majority of the interviewed teachers are passionate and motivated about helping their students deal with $\mathrm{EC}$ issues that riddle our daily lives. A supportive rather than limiting national educational strategy, that focuses on the broad concept of EC, would give them the room to implement 
EC more successfully. With a more suitable curriculum that includes opinion forming, ethics and other normative aspects of sustainability, a stronger focus on the competences needed for EC, and more opportunities to train their citizenship education skills, science teachers will have a higher chance of fostering EC with their lessons.

Supplementary Materials: The following are available online at https://www.mdpi.com/article/10 $.3390 /$ su13147963/s1: interview and coding scheme.

Author Contributions: Conceptualization, M.v.H., M.-C.P.J.K. and W.R.v.J.; methodology, M.v.H., M.C.P.J.K. and W.R.v.J.; formal analysis, M.v.H.; writing-original draft preparation, M.v.H.; writing-review and editing, M.v.H., M.-C.P.J.K. and W.R.v.J.; visualization, M.v.H.; supervision, M.-C.P.J.K. and W.R.v.J.; funding acquisition, M.v.H. and M.-C.P.J.K. All authors have read and agreed to the published version of the manuscript.

Funding: This research was funded by Nationaal Regieorgaan Onderwijsonderzoek (NRO), grant number 40.5.18540.030.

Institutional Review Board Statement: This study was performed under the ethical guidelines from the Faculty of Science from Utrecht University. Explicit ethical review for this study was not mandatory.

Informed Consent Statement: Informed consent was obtained from all subjects involved in the study.

Data Availability Statement: Data sharing not applicable.

Acknowledgments: We thank the involved teachers for making time for the interviews. We also thank the researcher who agreed to perform the intercoder reliability check. Finally, we would like to thank the reviewers for their useful commentary. The authors take full responsibility for the text of this article.

Conflicts of Interest: The authors declare no conflict of interest.

\section{References}

1. European Commission. Key Competences for Lifelong Learning; International Report; European Commission: Luxembourg, 2019. [CrossRef]

2. UN. The Sustainable Development Goals Report; International Report; United Nations: New York, NY, USA, 2019; ISBN 978-92-1-101403-7.

3. UNESCO. Shaping the Future We Want. UN Decade of Education for Sustainable Development (2005-2014); Final Report; UNESCO: Paris, France, 2014; ISBN 978-92-3-100053-9.

4. Borg, C.; Gericke, N.; Höglund, H.O.; Bergman, E. The barriers encountered by teachers implementing education for sustainable development: Discipline bound differences and teaching traditions. Res. Sci. Technol. Educ. 2012, 30, 185-207. [CrossRef]

5. Olsson, D.; Gericke, N.; Sass, W.; Boeve-de Pauw, J. Self-perceived action competence for sustainability: The theoretical grounding and empirical validation of a novel research instrument. Environ. Educ. Res. 2020, 26, 742-760. [CrossRef]

6. WCED. Our Common Future: The United Nations World Commission on Environment and Development; International Report; UN: Oslo, Norway, 1987.

7. Hadjichambis, A.C.; Paraskeva-Hadjichambi, D. Education for Environmental Citizenship: The Pedagogical Approach. In Conceptualising Environmental Citizenship for 21st Century Education; Hadjichambis, A.C., Paraskeva-Hadjichambi, D., Pauw, J.B., Knippels, M.C., Reis, P., Činčera, J., Gericke, N., Eds.; Springer: Cham, Switzerland, 2020; pp. 237-261. [CrossRef]

8. Westheimer, J.; Kahne, J. What Kind of Citizen? The Politics of Educating for Democracy. Am. Educ. Res. J. 2004, 41, 237-269. [CrossRef]

9. McKeown, R.; Hopkins, C. EE $\neq$ ESD: Defusing the worry. Environ. Educ. Res. 2003, 9, 117-128. [CrossRef]

10. Hammond, G.P. "People, planet and prosperity": The determinants of humanity's environmental footprint. Nat. Resour. Forum 2006, 30, 27-36. [CrossRef]

11. Kopnina, H. Revisiting education for sustainable development (ESD): Examining anthropocentric bias through the transition of environmental education to ESD. Sustain. Dev. 2014, 22, 73-83. [CrossRef]

12. Taylor, N.; Quinn, F.; Jenkins, K.; Miller-Brown, H.; Rizk, N.; Prodromou, T.; Serow, P.; Taylor, S. Education for Sustainability in the Secondary Sector-A Review. J. Educ. Sustain. Dev. 2019, 13, 102-122. [CrossRef]

13. Summers, M.; Childs, A.; Corney, G. Education for sustainable development in initial teacher training: Issues for interdisciplinary collaboration. Environ. Educ. Res. 2005, 11, 623-647. [CrossRef]

14. Sinakou, E.; Boeve-de Pauw, J.; van Petegem, P. Exploring the concept of sustainable development within education for sustainable development: Implications for ESD research and practice. Environ. Dev. Sustain. 2019, 21, 1-10. [CrossRef] 
15. Hasslöf, H.; Lundegård, I.; Malmberg, C. Students' qualification in environmental and sustainability education-epistemic gaps or composites of critical thinking? Int. J. Sci. Educ. 2016, 38, 259-275. [CrossRef]

16. Georgiou, Y.; Hadjichambis, A.C.; Hadjichambi, D. Teachers' Perceptions on Environmental Citizenship: A Systematic Review of the Literature. Sustainability 2021, 13, 2622. [CrossRef]

17. Bagoly-Simó, P. Tracing sustainability: Education for sustainable development in the lower secondary geography curricula of Germany, Romania, and Mexico. Int. Res. Geogr. Environ. Educ. 2014, 23, 126-141. [CrossRef]

18. Clément, P.; Caravita, S. Education for Sustainable Development: International Surveys on Conceptions and Postures of Teachers. In Topics and Trends in Current Science Education; Bruguière, C., Tiberghien, A., Clément, P., Eds.; Springer: New York, NY, USA, 2014; pp. 175-192. Available online: https:/ / hal.archives-ouvertes.fr/hal-01026085 (accessed on 4 June 2021).

19. Stichting Leerplanontwikkeling. Karakteristieken en Kerndoelen Onderbouw Voortgezet Onderwijs; Report; Stichting Leerplanontwikkeling: Enschede, The Netherlands, 2016.

20. Schulz, W.; Ainley, J.; Fraillon, J.; Losito, B.; Agrusti, G.; Friedman, T. Becoming Citizens in a Changing World: IEA International Civic and Citizenship Education Study; International Report; Springer Open: Cham, Switzerland, 2018. [CrossRef]

21. Kelly, T. Discussing controversial issues: Four perspectives on the teacher's role. Theory Res. Soc. Educ. 1986, 14, 113-138. [CrossRef]

22. Ojala, M. Safe spaces or a pedagogy of discomfort? Senior high-school teachers' meta-emotion philosophies and climate change education. J. Environ. Educ. 2020, 52, 40-52. [CrossRef]

23. Day, S.P.; Bryce, T.G.K. Does the discussion of socio-scientific issues require a paradigm shift in science teachers' thinking? Int. J. Sci. Educ. 2011, 33, 1675-1702. [CrossRef]

24. Dutta, D.; Chandrasekharan, S. Doing to being: Farming actions in a community coalesce into pro-environment motivations and values. Environ. Educ. Res. 2017, 24, 1192-1210. [CrossRef]

25. Boeve-de Pauw, J.; Gericke, N.; Olsson, D.; Berglund, T. The effectiveness of education for sustainable development. Sustainability 2015, 7, 15693-15717. [CrossRef]

26. United Nations. World Urbanization Prospects: The 2018 Revision, Online Edition; United Nations: New York, NY, USA, 2018; Available online: https:/ / population.un.org/wup/ (accessed on 4 June 2021).

27. Tschannen-Moran, M.; Woolfolk Hoy, A. Teacher Self-efficacy: Capturing an Elusive Construct. Teach. Teach. Educ. 2001, 17, 783-805. [CrossRef]

28. Glaser, B.G. The Constant Comparative Method of Qualitative Analysis. Soc. Probl. 1965, 12, 436-445. [CrossRef]

29. O'Connor, C.; Joffe, H. Intercoder Reliability in Qualitative Research: Debates and Practical Guidelines. Int. J. Qual. Methods 2020, 19, 1-13. [CrossRef]

30. Summers, M.; Childs, A. Student science teachers' conceptions of sustainable development: An empirical study of three postgraduate training cohorts. Res. Sci. Technol. Educ. 2007, 25, 307-327. [CrossRef]

31. Westheimer, J. On the Relationship between Political and Moral Engagement. In Getting Involved Global Citizenship Development and Sources of Moral Values; Veugelers, W., Tirri, K.A.H., Eds.; Brill: Leiden, The Netherlands, 2008; Volume 1, pp. 15-29. [CrossRef]

32. Estellés, M.; Fischman, G.E. Who Needs Global Citizenship Education? A Review of the Literature on Teacher Education. J. Teach. Educ. 2021, 72, 223-236. [CrossRef]

33. Almeida, A.; Vasconcelos, C. Teachers' Perspectives on the Human-Nature Relationship: Implications for Environmental Education. Res. Sci. Educ. 2013, 43, 299-316. [CrossRef]

34. Knippels, M.C.P.J.; van Harskamp, M. An Educational Sequence for Implementing Socio-Scientific Inquiry-Based Learning (SSIBL). Sch. Sci. Rev. 2018, 100, 46-52. 